Newfoundland and Labrador Studies

\title{
Aimee Wall. We, Jane
}

\section{Alexandra Trnka}

Volume 36, numéro 1, 2021

URI : https://id.erudit.org/iderudit/1082223ar

DOI : https://doi.org/10.7202/1082223ar

Aller au sommaire du numéro

\section{Éditeur(s)}

Faculty of Arts, Memorial University

\section{ISSN}

1719-1726 (imprimé)

1715-1430 (numérique)

Découvrir la revue

Citer ce compte rendu

Trnka, A. (2021). Compte rendu de [Aimee Wall. We, Jane]. Newfoundland and

Labrador Studies, 36(1), 157-161. https://doi.org/10.7202/1082223ar d'utilisation que vous pouvez consulter en ligne.

https://apropos.erudit.org/fr/usagers/politique-dutilisation/ 
Aimee Wall. We, Jane. Toronto: Book*hug Press, 2021. ISBN 978-1-77166-670-1

In her debut novel $W e$, Jane, Aimee Wall explores the unique precarity of living in outport Newfoundland and the complicated female partnerships that fill the gaps. We, Jane opens on Marthe, a thirty-something woman from rural Newfoundland. Her situation is familiar: Marthe lives in Montreal, works at a hip café where customers post stylized photos of their coffees on Instagram, and tries to grow roots in a city whose social scene seems perpetually beyond her reach. After getting an abortion Marthe tells us that within three months of meeting her ex-boyfriend, Karl, "he had accompanied her to the Morgentaler clinic" (15) - she attends a doula information session at a recreation centre in Montreal's wealthy Westmount neighbourhood, with the vague intention to train as an abortion doula. Here, among a group of "well-off, hippieish white ladies" (24), Marthe meets another woman from Newfoundland, who stands out from the others in the room: Jane, with "long, strong legs crossed ankle to knee like a man taking up space on the metro" (24). Jane is older than Marthe, and Jane is not her real name. She lets Marthe in on a secret: she is one of many Janes, a pseudonym shared by a covert group of women who live in outport Newfoundland and perform unregulated abortions for rural women without access to the province's abortion clinics in St. John's or Corner Brook. After a lengthy platonic courtship, Jane and Marthe set off on a road trip from Montreal to an unnamed Newfoundland outport community - "a small cove on the island, hours from town" (41) - to meet the original Jane, a woman named Trish who will train Marthe in the delicate art of DIY abortions.

Marthe's desire to subsume herself in Jane is borne as much from her personal experience with abortion as from her tendency, lately, of "envying any women she saw who seemed to be part of a clan" (17). Though abortion and its access are one of the novel's driving themes, most of the narrative pivots around Marthe's personal endeavour to figure out, plainly, what to do and where to live. This tension is specific to her position as a Newfoundlander living on the mainland, and the 
ambiguous pull she feels to move back to the island, all the while cognizant of how easily Newfoundland expats romanticize their return and forget that "there were fuck-all jobs, and didn't she remember about everyone being up each other's holes and knowing everyone else's business, and how everyone was already after sleeping with everyone else, and how it would just be the same old shit" (70). Marthe lives the life of many young Newfoundlanders who move to cities like Montreal or Toronto: one that can easily be stripped bare, when, for example, your live-in Danish boyfriend announces he is moving back to his home country with only a few days' notice.

Wall herself is a Newfoundland native who has settled in Montreal. Without indulging too deeply in the mirage of comparing an author's biography to those of her characters, I can say, as another young woman from Newfoundland who lives in the very same gentrifying Montreal neighbourhood as Marthe, that Wall's articulation of this feeling, of building a life from scratch in a place that doesn't quite feel yours, is potent.

We, Jane is fundamentally about precarity, not only in Marthe's somewhat tenuous existence in Montreal, or even Wall's attention to reproductive rights, but also through her focus on the increasing commodification of rural communities and Marthe's sense that the essence of these remote places is at risk. There is a fundamental tug of war at play, between the precarity of rural outport communities and their dependence on urban access on the one hand, and what Marthe considers the perverse threat of townie gentrification on the other, embodied in Jane's cove by "a young couple who had moved home from Toronto to open a restaurant as step one in a plan to make their hometown the next Trinity or Bonavista or Woody Point" (103). The necessity of urban access to obtain services like abortions seems to threaten the essential independence of the rural communities that require such resources. Jane is an answer to this precarity, as she insists on passing on the material knowledge of how to perform abortions to other local women, rather than depending on city clinics or even the newly approved medical abortion pill. 
In 2019, a Globe and Mail analysis found that the increased accessibility to abortion promised by the medical abortion pill was still restricted by numerous obstacles, including unwillingness of primarycare providers to prescribe the pill. This access still depends on whether rural doctors choose to undergo the required training to prescribe the pill and adopt its prescription as part of their practice. Institutional access to abortion does not satisfy Jane; "official blessing was never what Trish had been after," we learn, but rather "a living matriarchal line of knowledge ... to pass down the control but never hand it over" (44). We, Jane exposes the promise of stable institutional access as a myth, how precarity will persist despite new pills or clinics or laws that affirm abortion as an essential constitutional right. "What if it becomes all about the pills and then one day, the pills can't get in" (45), Jane asks. By insisting that the knowledge be passed through the hands, she circumvents this institutional precarity.

In 1987, one year before abortion became legal in Canada and three years before the first abortion clinic opened in St. John's, the Canadian Medical Association Journal (CMAJ) reported that women with the means would routinely travel to the Morgentaler clinic in Montreal to receive the procedure, the same clinic where Marthe receives her abortion in Wall's novel; "Morgentaler says he sees between 5 and 10 Newfoundlanders a week" (866). This $C M A J$ article ends with an observation that applies to Wall's portrayal of present-day rural Newfoundland: "In many small rural communities in Newfoundland, teenage girls who are sexually active are afraid to ask their doctors for advice and teenage boys are afraid to ask for [condoms] because the doctor or the druggist may be their neighbour or a family friend" (866). Though Wall does not situate the temporality of her novel specifically, this contrast, between the ease of access to abortion in Montreal and its scarcity in rural Newfoundland, pervades the current context of $W e$, Jane and allows the narrative to unfold.

Marthe's pseudo-paranoid suspicion of other young people in the community is legitimized at the novel's end, when Jane's story is exposed to the media by another young woman, a $\mathrm{PhD}$ student named 
Kara who visits from New York to receive an abortion from Jane herself. Kara had "written an article for a feminist magazine detailing her adventures in outsider reproductive health. She had gone to Spain and met the GynePunk women hacking reproductive technology .... and she had gone to rural Newfoundland and had an at-home abortion by an old midwife who claimed to be working in the tradition of Jane" (188-89). One of the novel's most interesting tensions derives from Marthe's similarity to Kara, a resemblance of which Marthe herself seems unaware. Marthe insists that she would never be "one of those people who breeze in from elsewhere for a month or two and decide to make a project, you know, "with the community" (147). And yet, at the novel's outset, she herself intends - somewhat satirically — to "write the Great Canadian Abortion Novel" (9). She herself goes through the process of "read[ing] about the GynePunk cyborg witches" and writing "the first paragraph of three different essays" (23). Though Marthe ultimately abandons her plan to create an art project in lieu of less conventional pursuits, one wonders whether part of her disdain for Kara may stem from Kara's completion of a creative project that Marthe abandoned.

We, Jane is not "the Great Canadian Abortion Novel," in part because such a title is an empty pedestal - how would one define such a book? - and in part because much of the narrative space is afforded to Marthe's inner conflict, her attempt to find a purpose in life and navigate her feelings about moving home. Though Wall's focus on rural reproductive access is timely and relevant, $W e$, Jane succeeds primarily through Wall's effective portrayal of these nuanced female relationships, as well as the compelling tension that occurs when the reality of Jane's project in rural Newfoundland first falls short of Marthe's romanticized revolutionary expectations. The patina of Marthe's mission dulls when she arrives on the island and finds the real thing to be more rugged, awkward, slow, and unplanned. We, Jane engages the topic of abortion but looks more closely, and deftly, at the social dynamics of activist work, and how this work is inextricable from personal pride, self-worth, and romanticized ideas about female friendship. 


\section{Works Cited}

Weeks, Carly. “Abortion-Pill Obstacles: How Doctors' Reluctance and Long-Distance Travel Stop Many Canadians from Getting Mifegymiso." Globe and Mail, 13 July 2019. https://www.theglobeandmail. com/canada/article-abortion-pill-obstacles-how-doctors-reluctance-and-long-distance/.

Yaffe, Barbara. "The Abortion Issue in Newfoundland: A Province Divided.” Canadian Medical Association Journal 136 (Apr. 1987): 865-66. https:// europepmc.org/backend/ptpmcrender.fcgi?accid=PMC1492119\&blobtype $=$ pdf.

Alexandra Trnka

Montreal 